\title{
Distance Learning - from Idea to Realization
}

\author{
Božo Nikolić and Ljiljana Ružić-Dimitrijević \\ The Higher Education Technical School of Professional Studies, \\ Novi Sad, Serbia
}

\author{
direktor@vtsns.edu.rs; ljaga@eunet.rs
}

\begin{abstract}
The development of information technologies provides a support to traditional teaching and even makes its replacement possible. There are numerous benefits from distance learning systems. Since distance learning is not flawless, the paper discusses its advantages and disadvantages alike. Among the latter are: motivation of teachers, abuse of teaching materials, verification of student knowledge, and level of previous knowledge necessary for this type of learning. However, the first and basic problem is whether the educational institution is ready to accept distance learning. The paper presents a positive example and explains why and how a distance learning system was introduced in the Higher Education Technical School. It deals with necessary equipment and resources, and with measures to adapt existing study programs and modify their courses to new circumstances. Although its implementation was not easy and demands constant improvement, distance learning was estimated as very important for the future of the School. The authors of the paper believe that their experiences in this field can serve as guidelines to others intending to set off a similar distance learning system.
\end{abstract}

Key words: traditional teaching, distance learning system, equipment, resources, assessment, course modification, survey

\section{Introduction}

\section{Distance learning is a process in which the source of knowledge and the learner are physically distance.}

Nowadays students are delighted with this way of learning, and gladly accept the idea to learn from electronic materials. Among other things, the success also depends on how this technology is applied. This way of learning enables students to work individually at their own pace using email and video conferencing or a local area network. The process takes place in real time. In principle, it is possible to study anywhere at any time. There are no more classes, periods, shifts and timetables. You can study as much as you like, when and where you want, because the whole world has become a classroom (Radosav, 2008).

Material published as part of this publication, either on-line or in print, is copyrighted by the Informing Science Institute. Permission to make digital or paper copy of part or all of these works for personal or classroom use is granted without fee provided that the copies are not made or distributed for profit or commercial advantage AND that copies 1) bear this notice in full and 2) give the full citation on the first page. It is permissible to abstract these works so long as credit is given. To copy in all other cases or to republish or to post on a server or to redistribute to lists requires specific permission and payment of a fee. Contact Publisher@InformingScience.org to request redistribution permission.
Distance learning began in England in 1840. It was implemented at London University in 1859 , and at the University of South Africa in 1946. The year 1965 can be taken as the starting point of the next stage of its development typical for rare computers complicated for programming and operation. The first "open universities" appeared in the United Kingdom and Germany in 1969 and 1974 respectively. Therefore, distance learning is often defined as Open and Distance 
Learning (6). Today it exists worldwide in numerous institutions. About 1972 began a more serious development of educational software and larger systems. It was followed by the introduction of personal computers and systems of artificial intelligence. The largest step forward in distance learning was due to the launch of the Internet and technologies connected to it (Marosan, 2006).

The implementation of information technologies in education enables a transition from collective education to individual, from passive to active education, instead of academic years there is a flexible distribution of knowledge acquisition, fixed examinations are replaced with continuous assessment (Radosav, 2008).

The development of modern information technologies provides a support to traditional teaching and even its replacement (Solakovic, 2007). The benefits of distance learning systems based on intelligent tutorial systems must satisfy the following conditions:

Autonomy from access time and service uses;

Autonomy from computer system;

Adjustment to individual user needs;

Monitoring of student advancement and testing; and

Implementation of other systems and upgrading of its own.

Characteristics of a distance learning system:

- Individual learning;

- Individual pace;

- Arbitrary learning time

- Arbitrary learning place

- Student takes responsibility;

- Interactivity;

- Physical separation;

- Illimitability of time and space;

- Self-verification of knowledge;

- Student cooperation; and

- One-to-one consulting.

Therefore, elementary characteristics of distance learning are its practicality, efficiency and flexibility. The quality of this kind of education depends on:

- Motivation and quality of students;

- Way of presentation and content quality;

- Level of interaction;

- Applied technique and available equipment, which influences course fees; and

- Competency and ability of teachers.

To reach quality and successful distance learning it is necessary to have management and administration systems for such processes in order to monitor them and control from the enrolment to graduation.

The implementation of state-of-the-art technology in distance learning influences the following:

- Raises the quality of learning;

- Diminishes costs; and 
- Increases the efficiency of education.

In traditional teaching the interaction with the student and individual activity are not provided. In our country according to official standards in higher education there are 60-student groups for auditory exercises, whereas groups for lectures are even larger; therefore, it is difficult to implement interactivity. Interactive learning is achieved through interactive multimedia technology, computer networks, and development of compact disk. Interaction can be established with the course content, experts, mentor, colleagues, etc.

Even though distance learning is adjusted to individual needs of the student, unlike traditional learning where attention is paid to the average student, distance learning has its flaws, and it is connected to certain problems.

The first and basic problem is whether the educational institution, i.e. its faculty, accepts this system, but it requires administrative support as well. The motivation of teachers and their fear from the abuse of teaching materials related to copyright and piracy should be mentioned, too. A special problem is the system of verification of student knowledge, and the level of their previous knowledge necessary for such learning.

In distance learning it is necessary to take care of teacher-student and student-student interactions, and to include student-environment interaction since without it distance learning is an unreal form. The interaction is enabled through electronic communication in the form of forums, chat rooms, videoconferences, etc.

Tuition fees are not negligible and distance learning allows substantial saving, not only in direct expenses of an individual, but also by introducing this system where one software can be used indefinitely, number of students is also indefinite, as well as the space, since it is possible to study from anywhere in the world. For instance, Australia is regarding its size and population a good example for the importance of distance learning (Rumble, 1992). Since we have students from neighboring countries and distant parts of our country, they find it convenient to study through distance learning.

When talking about distance learning, one can raise the question of student socialization and loneliness (Dake, 1987), lack of companionship among students (Radosav, 2005) due to distance learning. However, there are other examples showing the positive side of distance learning such as in teaching handicapped students with mild defects, which they see as more serious than they really are.

Distance education is successful and fulfills its goal if there is a good relationship between the teaching material, way of its presentation, and motivation and expectation of participants. The distance learning system allows a transition from collective to individual education, instead of traditional classrooms there are flexible groups.

Individualization in the teaching process is a method that considers student's personality and his/her abilities. This method is oriented and adjusted to an individual student. In addition, distance learning offers the replacement of passive acquisition of knowledge with active. Time for learning is no longer limited to academic years, but can extend during the entire life. The implementation of individualized tuition produces (Radosav, 2008) better educational effects of the whole tuition, faster students' progress and better motivation due to the application of multimedia educational software enabling more dynamic and interesting learning.

\section{How We Started}

The process of accreditation of educational institutions is in progress in our country; hence curricula and syllabi of study programs are being edited and adjusted according to the Bologna Dec- 
laration (Ruzic-Dimitrijevic \& Nikolic 2008). The accreditation is being conducted by the Accrediting Commission established by the government.

The Government National Counsel determined 12 standards for a study program that must be fulfilled for accreditation. The last of them regards distance learning. It requires a high quality of realization of the study program with tuition using a distance learning system (DLS). The education institution has to present the logistics and technological process of DLS. The following aspects are evaluated:

- How applied methods enable adopting of teaching material;

- If DLS develops individual abilities of students;

- How much the teacher-student consulting system helps independent learning;

- How the applied system of knowledge verification contributes to diploma equivalency in comparison to the traditional way of tuition; and

- The same competency and level of knowledge must be achieved like in the traditional way of learning.

The selected package of teaching material, the educational institution and its faculty must meet the following conditions:

- Syllabi are adapted to necessities and circumstances of distance learning;

- The teaching material covers the same content as in traditional learning; however, it is presented in a way appropriate to distance learning;

- DLS must contain instructions for the use of material, interactive discussions, and trial tests enabling more successful learning;

- The faculty must be qualified and competent for performing tuition using DLS;

- The control and assessment of student knowledge is conducted through different forms of pre-exam assignments, but the examination itself takes place in the school facilities; and

- The educational institution must be equipped adequately to realize distancelearning activities.

Estimating the importance of distance learning for the development of education in our country and holding that in the future it will be one of widely applied ways of learning, the School Council decided to start the realization of DLS. There are 14 study programs on undergraduate studies lasting three years mainly from engineering fields (mechanical, electrical, graphic, protection, and IT engineering). Each year, about 450 new students are enrolled and the majority are from the neighboring regions. They are full time or part time students, and some of them are employed.

We were aware of the difficulties and unknowns, because not a single state higher education institution in the country had done the same before us, so we had not a partner in our vicinity to share the experiences. However, we estimated that our resources are adequate (not only the equipment but human capacities as well), instructions and standards already existed, there was interest, and we started out the realization of this system of learning in just 2 out of 14 study programs of undergraduate studies.

\section{Equipment and Resources}

Our School is equipped with three independent networks. The first contains 60 computers (45 PCs and 15 notebooks) for the teaching process in classrooms and labs, and their users are stu- 
dents and teachers. The second has 30 PCs in teachers' offices. Besides, every teacher owns a notebook. The third network is for the staff: 5 computers are for the management, 7 for the student administration office, and 3 for the financial department. Each network is connected to the Internet by its own ADSL connection having the speed of $8 \mathrm{Mbps}$. The hardware and communication equipment allow a comfortable use of DLS.

The software for DLS is posted on a sub domain of the School's website hosted by one of domestic Internet providers (20GB of space, $200 \mathrm{~GB}$ of traffic, unlimited number of sub-domains and email addresses, support for PHP and MySql, CPanel, Fantastico deluxe).

The basis resource is software MOODLE (Modular Object-Oriented Dynamic Learning Environment). This package is an open-source community-based tool for learning available under GNU license. Moodle is a Course Management System (CMS), also known as a Learning Management System (LMS) or a Virtual Learning Environment (VLE). It is a free web application available to educators to create effective online learning sites. More than 30,000 educational institutions around the world currently use Moodle to deliver online courses and to supplement traditional face-to-face courses. Moodle is available for free on the Web (http://www.moodle.org) (Cole \& Foster, 2007).

Moodle was chosen because some of our teachers were familiar with the application and the possibility of free downloading. Additionally, several institutions in our environment had communicated their positive experiences about the software, and there is also a manual translated in our language.

These resources provide various forms of services: publicly broadcast lectures (direct or delayed), teaching material delivery, consulting through discussion forums, which is a framework for managed and informal teaching. User's interface supports a few categories of users (teachers, students, and administrative staff) and a two-way communication by e-mail, discussion forum and on-line discussion. The system reliability is high due to the control of access to the content and its protection.

DLS used by the School supports various learning forms but also includes a subsystem of knowledge verification. Discussion and workshop sessions are determinable, as well as times for submitting assignments and on-line consulting.

All teachers completed training for using the software, uploaded by themselves necessary teaching material and tests, and created other activities needed for achieving good results in the learning process. The activities include lectures, consultations, self-verification, projects, and tests.

Moodle allows logging in to DLS system as an administrator, teacher, student or guest. Teachers can create the program content and activities by using graphic interface.

The course content can be arranged as a weekly, thematic or social format. In a simple way teachers can add resources to their subjects like text pages, web pages, links to databases (Word, PPT, PDF, WMF, AVI,...), titles, indications, etc. as well as activities (forums, chats, tests, lessons, homework, etc.), which enables the extensive use of multimedia and hypermedia in teaching, and full interactivity in work between the teacher and the student, and among students themselves. There is a wide range of question types for tests: true/false, multiple choice, numerical, matching columns, cloze, and essay.

Each teacher edits his/her calendar of activities available to students, keeps a record of students, forms groups, supervises their activities within the course, marks them, manages their communication and collaboration, and provides back-up copies of all resources and activities, i.e., of the whole system. The system gives feedback and all other necessary information to students, assesses them automatically, provides communication and cooperation on assignments and projects, 
including full social interaction so that every student has access to profiles and photos of other colleagues.

Teachers determine criteria and scales of evaluation, and then the system itself automatically does the assessment according to the set rules estimating student activities and results. Time period of availability of test, number of access attempts (only one or more), whether questions change with each new attempt, and many other options can be predetermined.

One of essential characteristics of the system is the possibility of adaptive teaching by way of its resource "Lesson", where depending on student needs, previous knowledge, interests, one's personality and abilities, each student is lead in a different way through the educational material to make the process of learning more effective and efficient.

\section{Teaching Material and Methods Used in DLS}

We decided to organize DLS for two study programs accredited for the traditional way of teaching: Information technology and Fire protection. In the former program there is generally a great interest for studying and the material can be simply adapted for DLS, whereas in the latter there are a lot of potential students who cannot afford studying outside the place where they live.

Teachers developed teaching materials and activities in the DLS framework, according to contemporary needs to accomplish goals of distance education. The material is available on the School's sub domain www.dl.vtsns.edu.rs

The syllabi needed adapting of methods and forms (ways) of teaching. In the beginning teachers had difficulties in comprehending all required modifications, but during the process of change understood aims and means of their achievement, and began to realize advantages as well as disadvantages of the distance learning system.

Our agreement was to make a pattern for the organization of topics of all subjects. As the initial document, we created a list of basic information regarding the subject, its content, access way, student obligations, and assessment. Some teachers arranged their material on weekly basis, whereas others divided it into thematic fields, depending on the type of subject. Questions and tasks for self-verification follow shorter segments of the presented material like units, lectures, sections, etc.

Communication is achieved through discussion forums, chats, and e-mail. Forums serve to exchange ideas, attitudes, knowledge and experiences. Participants are students and teachers alike, who can select a theme for discussion. On-line chat is also predicted in most subjects for discussing in real time. In this way, students can develop critical thinking, hear and read opinions of others, and even improve their vocabulary and writing skills.

A lot of teachers pointed out the value of communication in DLS. Their remark, based on their experience, was that in traditional teaching there is a lack of communication. DLS students have a need to communicate and work interactively, but this aspect of tuition is partly ignored in the traditional teaching process. According to official standards in our country the number of students in a lecture group is 180, and auditory exercise groups have 60 students.

Although DLS offers flexible access timing, it is important to make students work constantly in order to achieve dynamic learning. This is accomplished by way of requests for submitting assignments and projects in time, and obligatory participation in discussions and chats.

Knowledge assessment is implemented continuously duration the course. This process includes the evaluation of student's activities (discussion forums, submitted assignments, projects, etc.). Tests are trial, only for self-verification, because of the recommendation of the Accrediting 
Commission. Since there is a low level of identity confirmation (due to limited requirements for technical equipment concerning students), the examination is held in the School premises.

Most of the material is structured as Word documents, Adobe .pdf, and PowerPoint presentations. Also, there are other multimedia contents like films, demonstrative software package for practicing applications, etc.

It is supposed that an average student enrolled in the course has the Internet access with speed of $56 \mathrm{Kbps}$, and a PC with restricted performances, which limits teaching means to those simple and easy to use.

As the study program of Fire protection includes subjects with laboratory exercises (chemistry, physics), their performance is planned in the School's laboratories during several joined periods within a few days (block teaching). The attendance of lab exercises is obligatory, but it is also a chance for students to meet teachers and each other in person.

\section{Critical Review of Designed Courses}

When creating the content and organization of work, teachers had to deal with a lot of doubts and dilemmas. Training for the use of the Moodle software package was a less difficult part of the job. However, it was far more complicated to think up a representative selection of the content, the way of its presentation and methods of work.

The question of copyright was raised regarding teachers and other authors whose material they wanted to use in teaching. Putting themselves in the student's position they soon realized it is not enough to scan textbooks or upload their electronic versions, for exhaustive instructions are also needed on how to use the material, ways of learning, obligations, and communication options with teachers and other students.

Teachers with the most extensive knowledge in this area (those teaching IT subjects) organized periodically a selection of temporarily top-ranked courses on the basis of posted recommendations. Thus, by applying mutual assessment and sharing of good ideas teachers improved their material for DLS.

Difficulties in the organization of work were presented concerning specific segments of some subjects, such as:

- laboratory exercises;

- way of assessment; and

- identification of students.

Teachers who better understood the application of distance learning explained their views on their own examples instructing others. Such meetings were held almost every day. Surprisingly, in spite of that it took us all three months of work to complete the subjects, which means there is a serious problem in planning the organization and way of work in courses thought through DLS.

Besides, we believe that none of the subjects was done either imperfectly or excellently, and during the application there will be inevitable changes. All teachers are aware of this.

Evaluation is a complex but necessary activity, which should be performed permanently, but with more intensity when designing the course organization in DLS. It is obvious that some courses could be set with less effort than others. Except for the nature of the course content, the reason for this lies in the teacher's competence regarding computer skills. 
Subjects from the information technology area are more suitable for this and teachers are experts in computer use. However, they had other challenges, since their courses are expected to be representative and high quality.

For example, the introductory subject from information technology that is common for all study programs, Computers, is presented in 15 weeks with lectures material in Word, Adobe, and PowerPoint documents, while exercises are given in demonstrative software application (Figure1).

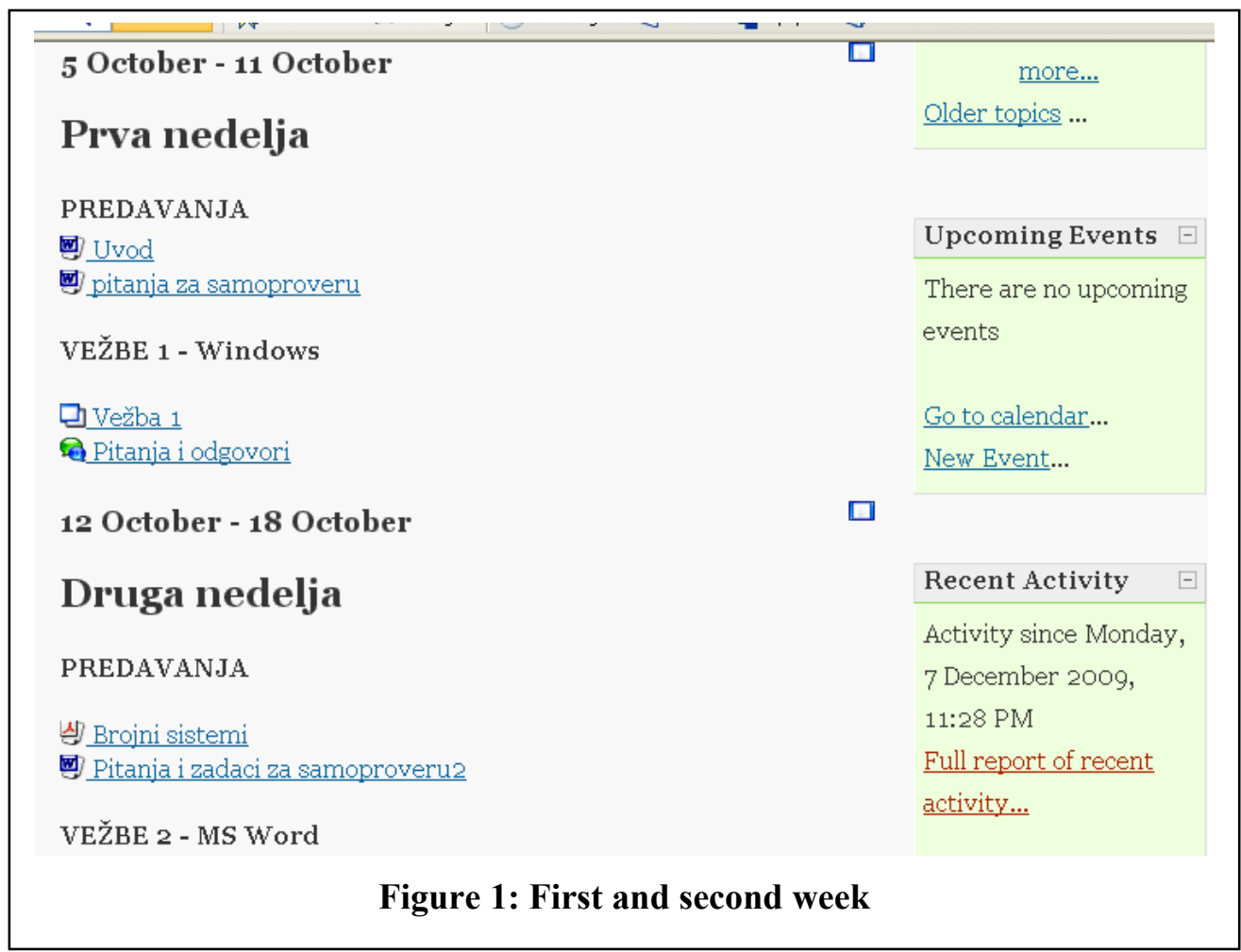

After guidelines for activities there is an example with a solution. The solution is given by use of a demonstrative application, and the student can follow the pattern (Figure 2) 


\section{Računari}

$\underline{\text { VTŠNS }}$ Rač

U Vežbi 4 savladaćemo sledeću materiju:

Rad sa stilovima (Styles and Formatting)

Header and Footer

Izvlačenje tabele sadržaja

Drawing ToolBar

Šabloni

Primer za vežbanje:

- Wordov dokument TEKST formirati po datom primeru: ○ Vežbanje 4

Rešenje UVECAN PRIKAZ

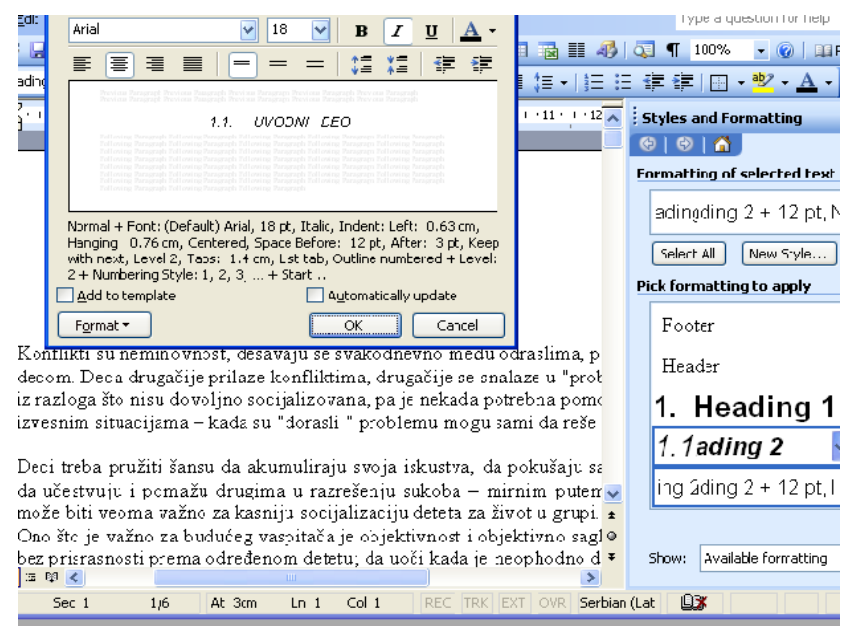

Figure 2: Exercise and solving

Every week students get a portion of theoretical material with self-verification questions, and exercises with explanations and a complete example. They have to do and submit 4 assignments after each presented area and a trial test in the $7^{\text {th }}$ week. The student can gather 30 points in this way, and the rest (70 maximum) in the examination on school premises. Forums and chats are intended mostly for teacher's explanations, and a share of experience between students.

The content organization by weeks is made also for the subject Introduction in web design. This subject requires more discussion through forums with comments and critical reviews considering the selected theme (Figure 3).

Re: PRVI UTISCI (Ideo.com / Jiong.com)

by Slavko Pekarić - Tuesday, 20 October 2009, 03:29 PM

1) O sajtu Ideo.com:

Dobar sajt, dosta sadržaja bez puno koda. Standardno korišce jedan nepopunjen atribut doduše, nije greska:

...div id="content" style="'"...

Korišćeno je dosta jQuery-evih funkcija za efekte, kako bi se š ucitava dugo spram kolicine podataka na strani.

Strukturu strane cine 3 glavna elementa (div-a): header, conte klasama i id-ovima kako bi se formatirali preko CSS fajla.
Re: PRVI UTISCI

by Bojan Mićić - Wednesday, 21 October 2009, 07:39 PM

http://www.e3.direktiv.com/

Ovaj sajt je maksimalno jednostavno urađen $\mathrm{i}$ veoma pregledar stave neki drugi font slova...

http://www.thevoid.co.uk/

Dugo traje uvodni deo i nije bas zanimljivo uradjen (jeste da mc privuče korisnije), svaka cast ako ga je neko odgledao do kraja.

Odgovor: PRVI UTISCI

by Nikola Stevanović - Thursday, 22 October 2009, 03:15 AM 1) http://www hotsprings.org/

Figure 3: Remarks on design of selected websites on forum 
Students have to participate on forums and to do a project assignment (designing of a website according to the requirements and subject matter). This brings 30-35 points, and the final assessment of the project and the test, which is done traditionally in the School at the examination, can bring maximum 65 points.

The subject Occupational health and safety belongs to Fire protection study program. This subject is divided in 4 segments, or themes (Figure 4). The recommended material consists of regulations and acts from the occupational safety area.

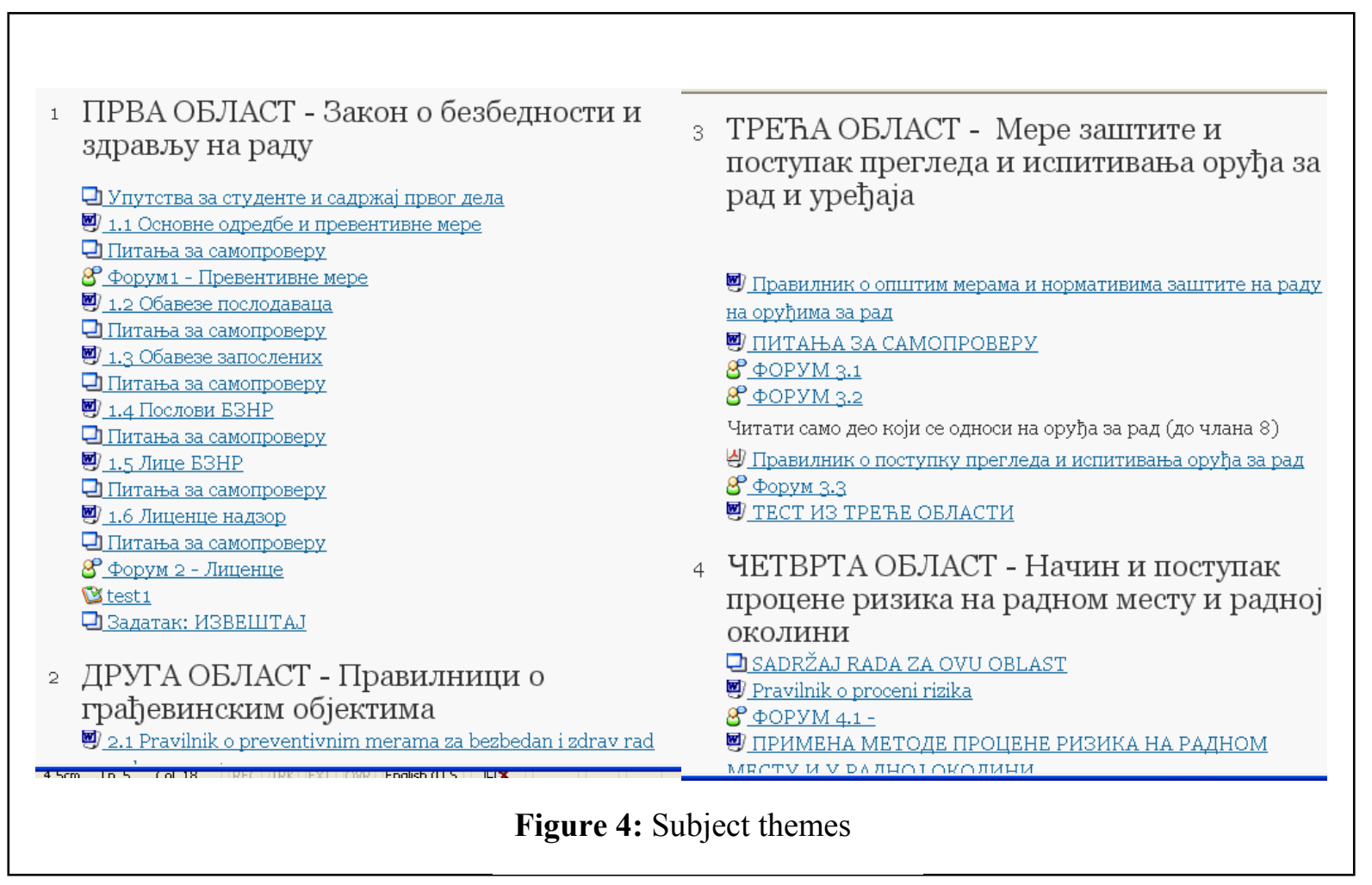

Time for adopting a theme is rather flexible, but there are obligations like answering questions posted on forums and doing trial tests. In addition, there are 2 project assignments that must be done until deadline dates. In order to do these projects the student has to gather data from practice. It means that he/she has to visit a company and do the projects applying the adopted subject matter in the activity.

It is significant that all courses have a similar organization, but with specific duties, according to the subject matter. Also, the assessment is carefully distributed, but the emphasis is on the traditional examination in the School due to the recommendation of the Accrediting Commission. This is a limiting factor with reference to DLS, but our society and educational system are at the very beginning of this learning and teaching process, so we are going step by step.

The real evaluation of the teaching material created for DLS is possible after the first group of students start learning in this way.

Until then some teachers decided to integrate e-learning elements in traditional classes, seeing advantages of using a "blended learning" approach. Many researchers emanated the significance of that hybrid teaching method (Smart \& Cappel 2006). E-learning elements can be used before 
or after traditional classes. In this way students are introduced with the new material for classes and more time can be spent on discussions, questions and problem solving.

Teachers include some assignments and materials of the e-learning platform (on the net) into their work with students who learn traditionally to motivate them to learn more actively.

\section{Survey Results}

In order to research new experiences on the activities concerning the implementation of DLS we conducted a survey among our teachers.

When the survey was conducted in the Higher Education Technical School, the activities on the preparation of subjects for distance learning were already going on. The number of professors and lecturers who took part in the survey is 30 . The age range is very wide, between 30 and 60 years. Professors mainly teach subjects from the technical and technological field, although there are courses that belong to the scientific and mathematical or artistic fields. Most teachers are doctors, whereas others are masters, and they already teach subjects prepared for DLS in the traditional way. All of them moderately use computers both at home and at work, and have school laptops with Internet connection at their disposal.

We have a lot of study programs lasting three or four years and ranging from art to metallurgy. One of them is Information technology. The School possesses a large number of computers, permanent Internet access, and a developed information system.

Some of the responses are graphically illustrated herein.

\section{What was your opinion about distance learning before you started using it?}
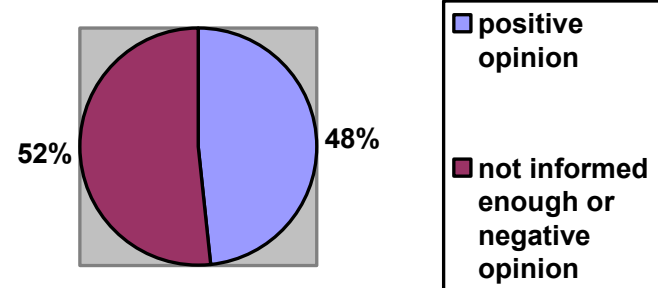

Figure 5: Before

More than half of the teachers did not have positive opinion on distance learning or they were not informed enough. 
2. What is your opinion about distance learning now when you modified the organization of your subject for distance learning?
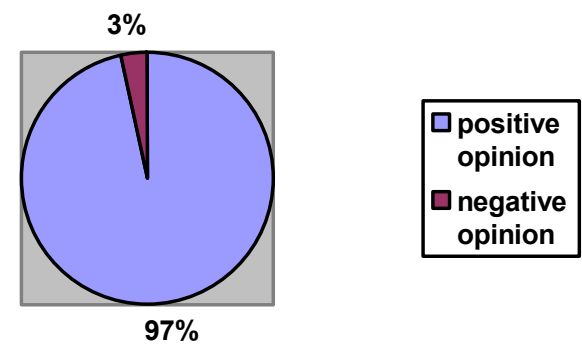

Figure 6: After

The majority of teachers changed their opinion at the end of the process, and answers predominantly expressed positive thinking about distance learning. However, most answers pointed to the need of good organization of work and constant improvement. This kind of work and all that followed was considered to be very difficult by the interviewed.

\section{Did you change your opinion about traditional teaching after this experience with} distance learning?

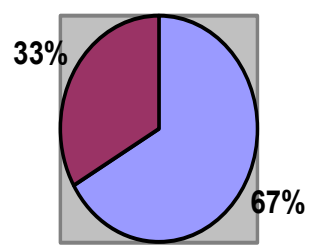

\section{ayes \\ ano}

Figure 7: Changing of opinion

Two thirds of the interviewees thought the experience had changed their attitude towards traditional teaching. The changes were positive and referred to the communication with students, examination, content systematization etc. Anyway, it seems the curriculum and syllabus "were cleaned up" a little bit. The remaining third said there was no change in their attitude.

\section{Do you think it is important for the future of the School to realize distance learning and to what extent?}

Without any exception all interviewees agreed that this was important. Over $80 \%$ said it was extremely important, and the remaining $20 \%$ said it was very important or important. They believed distance learning was of interest for the future of the School, for better enrolment and grater interest of students for the School, for its modernization and easier communication with greater environment.

There were a lot of comments referring to well-known advantages of distance learning. 
5. What caused you most trouble while preparing for distance learning?

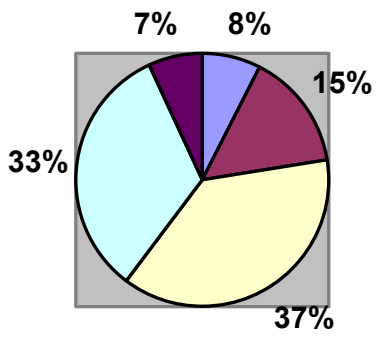

\begin{tabular}{|l}
$\square$ using \\
computer \\
$\square$ using Moodle \\
$\square$ planning \\
$\square$ technical \\
support \\
other
\end{tabular}

Figure 8: Dificulties

As expected, 37\% said the biggest problem was how to plan work on one's course in new circumstances. The same percentage pointed out technical support as a problem. Thanks to teacher training in the MOODLE program and good computer literacy only $23 \%$ of the interviewed had trouble with hardware or software use.

\section{What problems do you expect in the realization of distance learning?}

Typically, all participants were aware of difficulties and expected them in the future. Two things can be particularly pointed out: first, some teachers feared that students would not follow guidelines for learning; and second, poor computer skills of some students.

7. What results do you expect from students in distance learning in comparison to traditional learning?
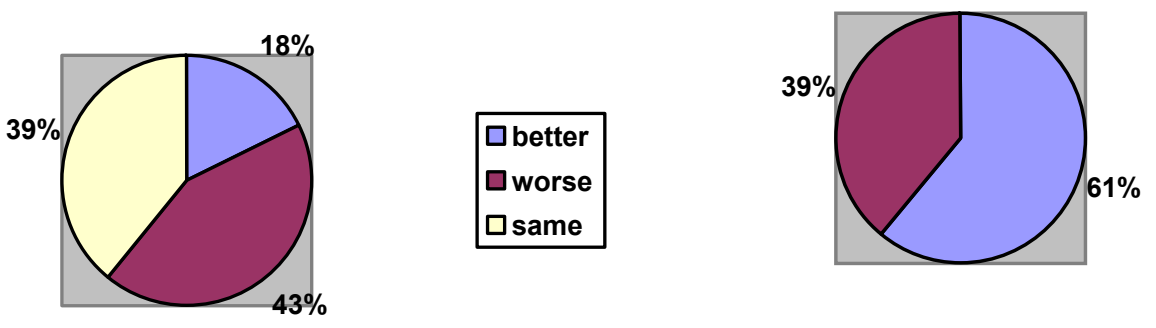

$\square$ better or the

\begin{tabular}{|l|}
$\square$ better \\
$\square$ worse \\
$\square$ same
\end{tabular}

$\square$ worse

Figure 9: Expected results

The answers differ, and two thirds believed that student results would be better or equal to the ones obtained traditionally, whereas the rest thought they would be worse.

8. Did you make any changes in your traditionally taught subjects due to the experiences with distance learning?

The answers are divided: $50 \%$ of the teachers did not make any modifications, whereas the other half did. 


\section{Survey Discussion}

Before the realization of the distance learning program, teachers of the School knew little about it and were reserved as well as the social environment we live in (Savic, 2006). After they became familiar with the distance learning system we use, the majority changed their opinion and attitude in the positive sense, and even benefited from the whole idea by innovation of their traditionally taught courses.

It is important to point out the teachers intend to include a more frequent use of media in teaching and other modern electronic methods. Self-verification of student knowledge is a new element in some cases.

The following was identified as distance learning advantages: greater interest to enroll the School, employed persons have a chance to study, interactivity, better verification of knowledge, continuous learning, smaller fees, etc. As disadvantages the teachers mentioned issues like: certain degree of previous knowledge is required, complex procedure, doubts about independent student work, jeopardized copyright, difficulties in checking practical student works, lack of contact, etc.

Generally, there were not many ideas for new questions. Those rare ones were about specific problems concerning individual subjects, users' reactions, socialization of students, copyright, and piracy.

Distance learning was estimated as very important for the future of the School, although its creation and implementation were rather difficult and demand constant improvement, but all difficulties can be surpassed.

In general, it is believed that mutual engagement of all participants in the learning process will provide at least the same competency level of undergraduate students as the one acquired in traditional learning.

\section{Conclusion}

The basic aim of the paper is to present the acceptance of the idea of distance learning in a higher education institution in a society where such way of learning has not been developed and has raised a lot of doubts.

This survey is a useful document for our institution as it gathers experiences with the implementation and organization of tuition within the selected distance learning system. A lot of questions could be raised: Is DLS suitable for every subject? Is it possible to offer and perform traditional and on-line teaching with the same quality? How to assess students? In spite of many challenges we can emphasize several positive facts.

The most important challenge was certainly to plan well each subject in order to motivate students, and achieve as good results in learning as possible. Many teachers started to appreciate student activities more due to DLS. Teachers realized that they have a better direct communication with the virtual student, than with the student face to face. Thanks to DLS some qualitative changes were made in teaching materials, a better communication has been developed, and students' attitude towards learning has generally improved. Some of the assignments and materials uploaded on-line are used in traditional classes, as well.

Once they accepted the task all teachers worked hard and responsibly trying to create programs as good as possible, knowing that DLS students should not become less competent than those learning traditionally.

The awareness of teachers has been changing in the sense that the old-fashioned and inert teacher, who is rather unavailable to the student, becomes modern not only for using up-to-date technolo- 
gies, but because of the newly developed relationship with students. We experienced this in just a few months of work, and we believe that further engagement in the area will contribute to additional positive developments of the awareness and relations.

Our experience could be very useful for all higher education institutions from our neighbored intending to start work on this issue. It is highly important that teachers understand the seriousness of the task expecting them in order to undertake it responsibly.

\section{References}

Cole, J., \& Foster, H. (2007). Using Moodle. O'Reilly Media, USA

Dale, S. (1987). Guidance for training in libraries: 8 Distance learning. London: The Library Association.

Marosan, Z. (2006). Ucenje na daljinu u zemljama tranzicije sa posebnim osvrtom na visoko obrazovanje u $A P$ Vojvodini [Distance learning in the states in transition, regards higher education in Vojvodina]. Doctoral dissertation, University in Novi Sad.

Martinez, D.S.M., Lambert J., Apollon, D., \& Branden J.V.D. (Eds.). (1997). Cultural and linguistic perspectives on European open and distance learning. TransCult, 1. University Granada

Radosav, D. (2005). Obrazovni racunarski softver i autorski sitemi, [Educational software and author's system]. University in Novi Sad, Serbia

Radosav, D. (2008). E-learning \& ODL tehnologije, Panevropski Aperion Univerzitet, Banja Luka

Rumble, G. (1992). The management of distance learning system. UNESCO: International Institute for Educational Planning

Ruzic-Dimitrijevic, L., \& Nikolic, B. (2008). Designing and building an information system for a higher education institution. Proceedings of the Informing Science and Information Technology Education Conference, InSITE 2008, Bulgaria.

Savic, A.,(2006). Metode razvoja i primena XML web servisa kao podrska tradicionalnom obrazovnom procesu [Methods of development and applying XML services like support of traditional educational process]. Doctoral dissertation, University in Novi Sad.

Smart, K., \& Cappel, J. (2006). Students' perceptions of online learning: A comparative study. Journal of Information Technology Education, 5, 201-219. Retrieved from http://www.jite.org/documents/Vol5/v5p201-219Smart54.pdf

Solakovic, I., (2007). Multimedijalni udzbenik u funkciji kvalitetne nastave [Multimedial textbook for quality teaching] Srpsko prosvetno i kulturno drustvo Republika Srpska

\section{Biographies}

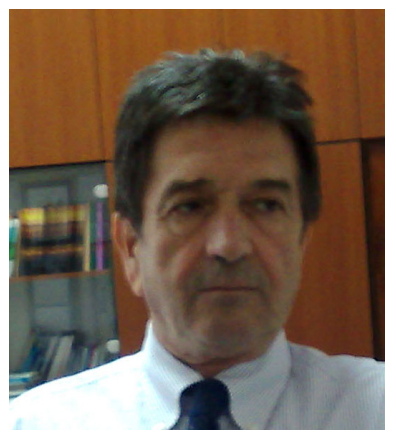

Bozo Nikolić is a professor at the Higher Education Technical School of Professional Studies, Novi Sad, Serbia. He teaches courses in the fields of mechanical engineering and labor safety. He got his $\mathrm{PhD}$ degree in mechanical engineering at the Belgrade University in 1998. His areas of expertise are tools, accessories, and risk assessment regarding workplace and workspace. He is director of the Higher Education Technical School of Professional Studies. 


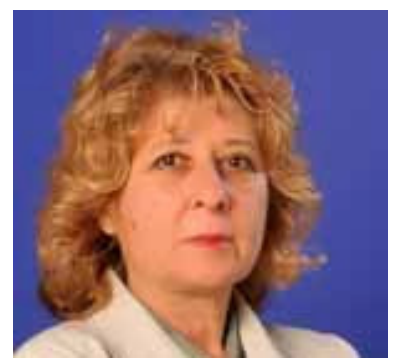

Ljiljana Ružić-Dimitrijević is a professor at the Higher Education Technical School of Professional Studies, Novi Sad, Serbia. She teaches courses in Computers, Introduction to web design, and Development of the Internet. She got her MSc degree in mathematics at the Centre of Multidisciplinary Studies, Belgrade in 1991. Her field of expertise is computer graphics and web design. She is pro-dean in charge of tuition. 